\title{
Regulation of heat-shock response in bacteria
}

\author{
E.Z. Ron ${ }^{1 *}$, G. Segal ${ }^{1+}$, R. Sirkis, M. Robinson ${ }^{2}$ and D. Graur ${ }^{2}$ \\ ${ }^{1}$ Department of Molecular Microbiology and Biotechnology, \\ ${ }^{2}$ Department of Zoology, George S. Wise Faculty of Life Sciences, \\ Tel-Aviv University, Tel-Aviv, Israel 69978 \\ ${ }^{+}$Present address: Department of Microbiology, Columbia University, New York, NY, USA
}

\begin{abstract}
Bacterial heat-shock response is a global regulatory system required for effective adaptation to changes (stress) in the environment. Several of the important genes involved in this control, such as the genes coding for the chaperones GroE and DnaK (the bacterial homologues of Hsp60 and Hsp70) are localized in operons, with organization typical of the phylogenetic group. In Escherichia coli, where it has been studied initially, the expression of the heat-shock operon is transcriptionally controlled by the employment of the heatshock transcription activator - factor $\sigma 32$, that recognizes specific heat-shock promoters. Later studies indicated that in most bacteria the control of these heat-shock operons is more complex than in the $\gamma$-purple proteobacteria and involves several regulatory elements. One such control element is a repressor that regulates transcription of heat-shock genes by binding to a conserved regulatory inverted repeat (IR=CIRCE) located upstream to heatshock operons. In addition, this IR determines the stability of the transcript, thus controlling the level of translation. Sequence analyses suggest that the IR-dependent control of heatshock genes was the first control element and was lost during evolution in several phylogenetic groups, such as the $\gamma$-purple proteobacteria.
\end{abstract}

\section{Introduction}

The heat-shock response involves the induction of many proteins - called heat-shock proteins, or Hsp's - in response to elevation of temperature (37). The bacterial heat-shock response is not limited to changes in temperature and is a general stress response, as many of the heat-shock proteins are induced by other environmental changes, such as the addition of ethanol, heavy metals, high osmolarity, pollutants, starvation or interaction with eukaryotic hosts $(3,16,34,50,51)$. The heat-shock proteins include chaperones and proteases that are presumably essential for overcoming changes that involve protein denaturation. Induction of this response improves thermotolerance, salt tolerance and tolerance to heavy metals $(18,24,25,38,52)$. Moreover, in several bacterial species heatshock proteins have been shown to play an important role in pathogenesis $(5,7,22,23,26-$ $29,31,41,47)$ and survival within macrophages (2). Heat-shock proteins are also essential for stationary phase (34) and for bacterial differentiation in myxobacteria and in Bacillus subtilis $(12,53)$.

The heat-shock response controls the expression of more than 20 genes $(9,37)$ that code for chaperones, proteases and regulatory proteins. Two of these proteins, Hsp70 (the

Microbial Biosystems: New Frontiers

Proceedings of the ${ }^{\text {th }}$ International Symposium on Microbial Ecology

Bell CR, Brylinsky M, Johnson-Green P (eds)

Atlantic Canada Society for Microbial Ecology, Halifax, Canada, 1999. 
product of the bacterial dnaK gene), and the Hsp10+Hsp60 complex (products of the groESL operon), act as chaperones, are highly conserved $(6,15)$, and have been extensively studied in many organisms, including a large variety of bacterial species. The present review deals with the various bacterial strategies for regulating the heat-shock response.

\section{Activation of specific heat-shock promoters by an alternative sigm factor (heat-shock sigma factor, or $\sigma 32$ )}

In bacteria, the major control of the expression of heat-shock genes is transcriptional. In Escherichia coli the heat-shock response is controlled by a specific sigma factor that activates the transcription of heat-shock genes under the appropriate conditions. This heatshock sigma factor $(\sigma 32)$ is coded by the $r p o H$ gene and binds to specific heat-shock promoters located upstream of heat-shock genes $(4,10,11,30,48)$. The expression of the rрoH gene is under complex regulation $(21,30,36,56)$, and under non heat-shock conditions its product is degraded by a specific protease, the product of the $h f l B(f t s H)$ gene $(8,13,14,17,20,21,49)$. The consensus sequence of the heat-shock promoter has been identified upstream of many heat-shock genes, and no other control elements have been found.

\section{Transcriptional activation of heat-shock genes by release of repression involving an inverted repeat (IR, CIRCE) and a repressor protein (product of the hrcA gene)}

In low-G+C gram positive bacteria, such as Bacillus subtilis, the heat-shock genes are transcribed by the vegetative sigma factor $(\sigma 70)$, and heat-shock induction is mediated by the release of a repressor that under non-heat conditions is bound to an inverted repeat located at the upstream regulatory region of heat-shock operons. This inverted repeat (IR) also called CIRCE (controlling IR of chaperone expression) - acts as the binding site for the repressor protein Orf39 (or OrfA, in B. subtilis), the product of the hrcA gene.

Deletions of the IR result in constitutive expression of the operon $(1,16,19,33,39,40,42$, $45,46,54,55,57)$. The IR is highly conserved as demonstrated in Fig. 1.and has so far been found only in the upstream region of $g r o E$, dnaK and $d n a J$ operons.

Mycobacterium tuberculosis
Staphylococcus aureus
Bacillus subtilis
Chlamydia pneumoniae
Brucella abortus
Bordetella pertusis

cTAGCACTC-N9-GAGTGCTAg TTAGCACTC-N9-aAGTGCTAA TTAGCACTC-N9-GAGTGCTAA TTAGCACT t-N9-GAGTGCTAA TTAGCACTC-N9-GAGTGCTAA TTAGCACTC-N9-GAGTGCTAA

Fig. 1. The conserved inverted repeat in heat-shock operons.

\section{Transcriptional activation of heat-shock genes in $\alpha$-purple proteobacteria}

In bacteria belonging to the $\alpha$ subdivision of proteobacteria - Agrobacterium tumefaciens, Bradyhizobium japonicum and Caulobacter crescentus, the IR element is present in the groE operon or in one of the groE operons in bacteria that have more than one such operons $(32,46)$ but not in any of the dnaK operons. All the heat-shock operons of $\alpha-$ 
purple proteobacteria contain a unique heat-shock promoter, presumbaly activated by a sigma 32-like transcription factor (43). The putative consensus heat-shock promoter is different from both the vegetative and the heat-shock promoter consensus sequences of $E$. coli. The unique heat-shock promoter is transcribed by a heat-shock activator, $\sigma 32$-like factor that differs from its homologue of the $\gamma$-purple proteobacteria in several regulatory aspects, as well as in promoter recognition $(35,36,43)$.

Experimental results indicate that the $\sigma 32$-like transcription factor controls the heatshock activation of the $d n a K$ operons as well as the groE operons while the IR functions to repress transcription of the groE operon under non heat-shock conditions (45). This situation is different from the low $\mathrm{G}+\mathrm{C}$ gram positive bacteria where the IR actually controls the heat-shock gene activation.

\section{Post transcriptional control elements}

The control mechanisms described above act at the level of transcription. Two additional regulatory elements of the heat-shock response are post-transcriptional. The first mechanism involves regulation of the stability of transcripts containing the IR in their upstream portion. In B. subtilis and in A. tumefaciens $(45,54)$, the half life of the groEL transcript increased two fold under non heat-shock conditions when deletions were introduced into the IR. The second post-transcriptional control was demonstrated in $A$. tumefaciens and involves specific cleavage of the groESL operon transcript (44), leading to differential expression of the two genes of the operon. This mRNA processing is temperature-dependent and is probably the first example of a controlled processing of transcripts in bacteria.

\section{Phylogenetic aspects}

The evolution of the various strategies for controlling the heat-shock response is an interesting problem. The phylogenetic analysis based on the non synonymous substitutions of groE and $d n a K$ indicates that the control system involving the repressor-binding IR (CIRCE) is the ancient control mechanism. It was lost first in the dnaK operons, three times in Cyanobacteria, in Streptomyces and in the purple proteobacteria ( $\alpha, \beta$ and $\gamma$ subdivision). The next event resulted in the loss of the IR from the groE operon in one family - the $\gamma 2 / \gamma 3$ subdivision of purple bacteria. The latter family is the only eubacterial family that controls the heat-shock response solely with an alternative sigma factor.

\section{Acknowledgements}

This work was supported in part by a grant from the Israel Academy of Science and by the Manja and Morris Leigh Chair for Biophysics and Biotechnology.

\section{References}

1. Bahl H, Muller H, Behrens S, Joseph H, Narberhaus F (1995) Expression of heatshock genes in Clostridium acetobutylicum. FEMS Microbiol Rev 17: 41-348

2. Baumler AJ, Kusters JG, Stojiljkovic I, Heffron F (1994) Salmonella typhimurium loci involved in survival within macrophages. Infect Immun 62:1623-1630

3. Blom A, Harder W, Matin A (1992) Unique and overlapping pollutant stress proteins of Escherichia coli. Appl Env Microbiol 58:331-334 
4. Bloom M, Skelly S, VanBogelen R, Neidhardt F, Brot N, Weissbach H (1986) In vitro effect of the Escherichia coli heat-shock regulatory protein on expression of heat-shock genes. J Bacteriol 166:380-384

5. Bohne J, Sokolovic Z, Goebel W (1994) Transcriptional regulation of prfA and PrfA-regulated virulence genes in Listeria monocytogenes. Mol Microbiol 11:11411150

6. Boorstein WR, Ziegelhoffer T, Craig EA (1994) Molecular evolution of the HSP70 multigene family. J Mol Evol 38:1-17

7. Brunham RC, Peeling RW (1994) Chlamydia trachomatis antigens: role in immunity and pathogenesis. Infect Agents Dis 3:218-233

8. Buchberger A, Schroder H, Hesterkamp T, Schonfeld HJ, Bukau B (1996) Substrate shuttling between the DnaK and GroEL systems indicates a chaperone network promoting protein folding. J Mol Biol 261:328-333

9. Chuang SE, Blattner FR (1993) Characterization of twenty-six new heat-shock genes of Escherichia coli. J Bacteriol 175:5242-5252

10. Cowing DW, Bardwell JC, Craig EA, Woolford C, Hendrix RW, Gross CA (1985) Consensus sequence for Escherichia coli heat-shock gene promoters. Proc Natl Acad Sci U S A 82:2679-2683

11. Cowing DW, Gross CA (1989) Interaction of Escherichia coli RNA polymerase holoenzyme containing sigma 32 with heat-shock promoters. DNase I footprinting and methylation protection. J Mol Biol 210:513-520

12. Deuerling E, Mogk A, Richter C, Purucker M, Schumann W (1997) The ftsH gene of Bacillus subtilis is involved in major cellular processes such as sporulation, stress adaptation and secretion. Mol Microbiol 23:921-933

13. Gamer J, Multhaup G, Tomoyasu T, McCarty JS, Rudiger S, Schonfeld HJ, Schirra C, Bujard H, Bukau B (1996) A cycle of binding and release of the DnaK, DnaJ and GrpE chaperones regulates activity of the Escherichia coli heat-shock transcription factor sigma32. Embo J 15:607-617

14. Gottesman S (1996) Proteases and their targets in Escherichia coli. Annu Rev Genet 30:465-506

15. Gupta RS (1995) Evolution of the chaperonin families (Hsp60, Hsp10 and Tcp-1) of proteins and the origin of eukaryotic cells. Mol Microbiol 15:1-11

16. Hecker M, Schumann W, Volker U (1996) Heat-shock and general stress response in Bacillus subtilis. Mol Microbiol 19:417-428

17. Herman C, Thevenet D, R DA, Bouloc P (1995) Degradation of sigma 32, the heatshock regulator in Escherichia coli, is governed by HflB. Proc Natl Acad Sci U S A 92:3516-3520

18. Inbar O, Ron EZ (1993) Induction of cadmium tolerance in Escherichia coli K-12. FEMS Lett 113:197-200

19. Jayaraman GC, Penders JE, Burne RA (1997) Transcriptional analysis of the Streptococcus mutans $h r c A, g r p E$ and $d n a K$ genes and regulation of expression in response to heat-shock and environmental acidification. Mol Microbiol 25:329-341

20. Kandror O, Busconi L, Sherman M, Goldberg AL (1994) Rapid degradation of an abnormal protein in Escherichia coli involves the chaperones GroEL and GroES. J Biol Chem 269:23575-23582 
21. Kanemori M, Nishihara K, Yanagi H, Yura T (1997) Synergistic roles of HslVU and other ATP-dependent proteases in controlling in vivo turnover of sigma32 and abnormal proteins in Escherichia coli. J Bacteriol 179:7219-7225

22. Karunasagar I, Lampidis R, Goebel W, Kreft J (1997) Complementation of Listeria seeligeri with the plcA-prfA genes from $L$. monocytogenes activates transcription of seeligerolysin and leads to bacterial escape from the phagosome of infected mammalian cells. FEMS Microbiol Lett 146:303-310

23. Kaufmann SH (1992) Heat-shock proteins in health and disease. Int J Clin Lab Res 21:221-226

24. Kusukawa N, Yura T (1988) Heat-shock protein GroE of Escherichia coli: key protective roles against thermal stress. Genes Dev 2:874-882

25. LaRossa RA, Van Dyk TK (1991) Physiological roles of the DnaK and GroE stress proteins: catalysts of protein folding or macromolecular sponges? Mol Microbiol 5:529-534

26. Lathigra RB, Butcher PD, Garbe TR, Young DB (1991) Heat-shock proteins as virulence factors of pathogens. Curr Top Microbiol Immunol 167:125-143

27. Macario AJ (1995) Heat-shock proteins and molecular chaperones: implications for pathogenesis, diagnostics, and therapeutics. Int J Clin Lab Res 25:59-70

28. Mager WH, De Kruijff AJ (1995) Stress-induced transcriptional activation. Microbiol Rev 59:506-531

29. Mauchline WS, James BW, Fitzgeorge RB, Dennis PJ, Keevil CW (1994) Growth temperature reversibly modulates the virulence of Legionella pneumophila. Infect Immun 62:2995-2997

30. McCarty JS, Rudiger S, Schonfeld HJ, Schneider Mergener J, Nakahigashi K, Yura T, Bukau B (1996) Regulatory region C of the E. coli heat-shock transcription factor, sigma32, constitutes a DnaK binding site and is conserved among eubacteria. J Mol Biol 256:829-837

31. McKay DB, Lu CY (1991) Listeriolysin as a virulence factor in Listeria monocytogenes infection of neonatal mice and murine decidual tissue. Infect Immun 59:4286-4290

32. Minder AC, Narberhaus F, Babst M, Hennecke H, Fischer HM (1997) The dnaKJ operon belongs to the sigma32-dependent class of heat-shock genes in Bradyrhizobium japonicum. Mol Gen Genet 254:195-206

33. Mogk A, Homuth G, Scholz C, Kim L, Schmid FX, Schumann W (1997) The GroE chaperonin machine is a major modulator of the CIRCE heat-shock regulon of Bacillus subtilis. Embo J 16:4579-4590

34. Muffler A, Barth M, Marschall C, Hengge Aronis R (1997) Heat-shock regulation of sigmaS turnover: a role for DnaK and relationship between stress responses mediated by sigmaS and sigma32 in Escherichia coli. J Bacteriol 179:445-452

35. Nakahigashi K, Yanagi H, Yura T (1995) Isolation and sequence analysis of rpoH genes encoding sigma 32 homologs from gram negative bacteria: conserved mRNA and protein segments for heat-shock regulation. Nucleic Acids Res 23:4383-4390

36. Nakahigashi K, Yanagi H, Yura T (1998) Regulatory conservation and divergence of sigma32 homologs from gram- negative bacteria: Serratia marcescens, Proteus 
mirabilis, Pseudomonas aeruginosa, and Agrobacterium tumefaciens. J Bacteriol 180:2402-2408

37. Neidhardt F, VanBogelen RA. (1987) Heat shock response. In: Escherichia coli and Salmonella typhimurium., vol. 2 (Neidhardt, F. C., Ingraham, J. L., K.B.Low, Magasanik, B., Schaechter, M. and Umbarger, E., eds.), pp. 1334-1345, American Society of Microbiology, Washington, D.C.

38. Qi H, Menzel R, Tse Dinh YC (1996) Effect of the deletion of the sigma 32dependent promoter (P1) of the Escherichia coli topoisomerase I gene on thermotolerance. Mol Microbiol 21:703-711

39. Roberts RC, Toochinda C, Avedissian M, Baldini RL, Gomes SL, Shapiro L (1996) Identification of a Caulobacter crescentus operon encoding $h r c A$, involved in negatively regulating heat-inducible transcription, and the chaperone gene grpE. $\mathrm{J}$ Bacteriol 178:1829-1841

40. Schulz A, Schumann W (1996) hrcA, the first gene of the Bacillus subtilis dnaK operon encodes a negative regulator of class I heat-shock genes. J Bacteriol 178:1088-1093

41. Schurr MJ, Deretic V (1997) Microbial pathogenesis in cystic fibrosis: co-ordinate regulation of heat-shock response and conversion to mucoidy in Pseudomonas aeruginosa. Mol Microbiol 24:411-420

42. Segal G, Ron EZ (1993) Heat-shock transcription of the groESL operon of Agrobacterium tumefaciens may involve a hairpin-loop structure. J Bacteriol 175:3083-3088

43. Segal G, Ron EZ (1995) The dnaKJ operon of Agrobacterium tumefaciens: transcriptional analysis and evidence for a new heat-shock promoter. J Bacteriol 177:5952-5958

44. Segal G, Ron EZ (1995) The groESL operon of Agrobacterium tumefaciens: evidence for heat-shock-dependent mRNA cleavage. J Bacteriol 177:750-757

45. Segal G, Ron EZ (1996) Heat-shock activation of the groESL operon of Agrobacterium tumefaciens and the regulatory roles of the inverted repeat. $\mathrm{J}$ Bacteriol 178:3634-3640

46. Segal R, Ron EZ (1996) Regulation and organization of the groE and dnaK operons in Eubacteria. FEMS Microbiol Lett 138:1-10

47. Sheehan B, Kocks C, Dramsi S, Gouin E, Klarsfeld AD, Mengaud J, Cossart P (1994) Molecular and genetic determinants of the Listeria monocytogenes infectious process. Curr Top Microbiol Immunol 192:187-216

48. Straus DB, Walter WA, Gross CA (1987) The heat-shock response of E. coli is regulated by changes in the concentration of sigma 32. Nature 329:348-351

49. Tomoyasu T, Gamer J, Bukau B, Kanemori M, Mori H, Rutman AJ, Oppenheim AB, Yura T, Yamanaka K, Niki H. (1995) Escherichia coli FtsH is a membrane-bound, ATP-dependent protease which degrades the heat-shock transcription factor sigma 32. Embo J 14:2551-2560

50. Van bogelen R, Kelley PM, Neidhardt F (1987) Differential induction of heat-shock, SOS and oxidation stress regulons and accumulation of nucleotides in Escherichia coli. J Bacteriol 169:26-32 
51. Van Dyk TK, Reed TR, Vollmer AC, LaRossa RA (1995) Synergistic induction of the heat-shock response in Escherichia coli by simultaneous treatment with chemical inducers. J Bacteriol 177:6001-6004

52. Volker U, Mach H, Schmid R, Hecker M (1992) Stress proteins and cross-protecion by heat-shock and salt stress in Bacillus subtilis. J Gen Microbiol 138:2125-2135

53. Yang Z, Geng Y, Shi W (1998) A DnaK homolog in Myxococcus xanthus is involved in social motility and fruiting body formation. J Bacteriol 180:218-224

54. Yuan G, Wong SL (1995) Isolation and characterization of Bacillus subtilis groE regulatory mutants: evidence for orf39 in the dnaK operon as a repressor gene in regulating the expression of both groE and dnaK. J Bacteriol 177:6462-6468

55. Yuan G, Wong SL (1995) Regulation of groE expression in Bacillus subtilis: the involvement of the sigma A-like promoter and the roles of the inverted repeat sequence (CIRCE). J Bacteriol 177:5427-5433

56. Yura T (1996) Regulation and conservation of the heat-shock transcription factor sigma32. Genes Cells 1:277-284

57. Zuber U, Schumann W (1994) CIRCE, a novel heat-shock element involved in regulation of heat-shock operon dnaK of Bacillus subtilis. J Bacteriol 176: 1359-1363 